\title{
Obituary: Victor M. Goldberg MD (1939-2015)-A Remembrance
}

\author{
Anthony Calabro MA
}

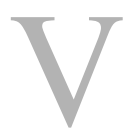

ictor M. Goldberg MD, longtime member of the Association of Bone and Joint Surgeons ${ }^{\circledR}$, passed away while vacationing in India with his wife Harriet on February 8, 2015 at the age of 75.

A world-renowned expert in joint replacement surgery, Dr. Goldberg's remarkable career spanned more than 40 years and touched upon all corners of orthopaedics, from biomechanics [2] to implant design [3], to stem-cell research in osteoarthritis [1].

Born June 11, 1939, Dr. Goldberg joined the United States Air Force in 1966, following an internship at University Hospitals Case Medical Center. After his discharge from the

The author certifies that he, or any members of his immediate family, has no commercial associations (eg, consultancies, stock ownership, equity interest, patent/licensing arrangements, etc) that might pose a conflict of interest in connection with the submitted article.

The opinions expressed are those of the writers, and do not reflect the opinion or policy of $\operatorname{CORR}^{\mathbb{R}}$ or the Association of Bone and Joint Surgeons ${ }^{\circledR}$.

\section{A. Calabro MA $(\square)$}

Clinical Orthopaedics and Related

Research $\AA, 1600$ Spruce Street,

Philadelphia, PA 19013, USA

e-mail: acalabro@clinorthop.org
Air Force in 1968, Dr. Goldberg was accepted as a resident at the Hospital for Special Surgery in New York, NY, USA. In 1971, he accepted an orthopaedic fellowship from Middlesex University in London, UK. He returned to the United States in 1972 and

joined the faculty of Case Western Reserve University and University Hospitals Case Medical Center in Cleveland, $\mathrm{OH}$.

An excellent surgeon, passionate clinician, and dedicated educator, Dr. Goldberg spent his entire professional

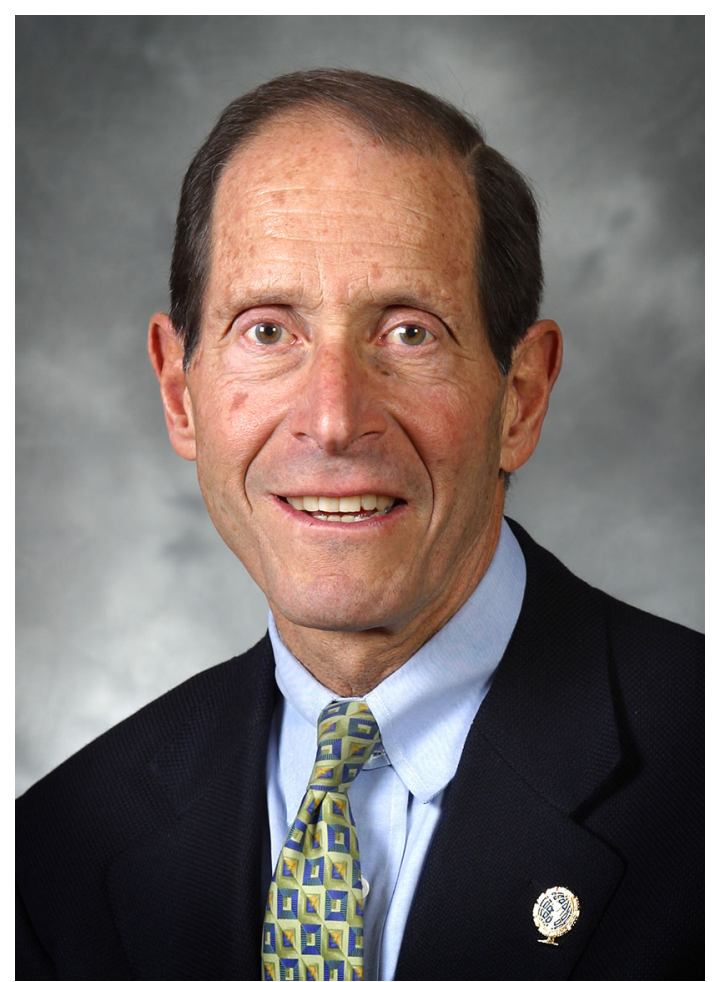

Fig. 1 An excellent surgeon, passionate clinician, and dedicated educator, Dr. Goldberg spent his entire professional career (1972-2015) at Case Western Reserve University and University Hospitals. 
career (1972-2015) at Case Western Reserve University and University Hospitals, where he served as the Charles H. Herndon Professor and Chairman of the Department of Orthopaedics from 1989 to 2002 (Fig. 1). Dr. Randall Marcus followed Dr. Goldberg as Charles H. Herndon Professor and Chairman in 2003, and has known Dr. Goldberg for 40 years.

"The best description I've heard of Victor is: 'Relentless pursuit of excellence,"' Dr. Marcus told Clinical Orthopaedics and Related Research ${ }^{\circledR}$ in a phone interview. "He was a dedicated surgeon and scientist who truly cared about his family and orthopaedic surgery. A true clinician-scientist."

Dr. Goldberg was not only an internationally renowned expert in orthopaedic surgery, he also possessed the unique ability to accurately communicate with and easily collaborate alongside peers in all areas of the specialty.

"They don't make them like him anymore," Jorge Galante MD told $C_{O R R^{\circledR}}$ in a phone interview. "Most people have that one trait that makes them different, but Victor was truly unique. He had that innate ability to understand the future and how to approach the future. He was one of our best investigators-biological issues, biomechanics, cell research, basic science-Victor researched it all."

The National Institutes of Health awarded Dr. Goldberg eight research grants, an extraordinary number for someone who was not a full-time researcher. A three-time winner of the American Academy of Orthopaedic Surgeons Kappa Delta Award for Excellence in Research (1985, 1992, 2003), the highest award for research given by the American Academy of Orthopaedic Surgeons, Dr. Goldberg published more than 250 manuscripts in peer-reviewed journals. He wrote more than 20 book chapters and authored or edited 10 books.
"He touched thousands of people through his abilities as an orthopaedic surgeon, but his contributions to the medical literature and research had a direct impact on countless lives throughout the world," Dr. Marcus said. "If you had joint replacement surgery, there is a good chance you were impacted by Dr. Goldberg just through his research alone."

Dr. Goldberg could be an intimidating mentor-his residents

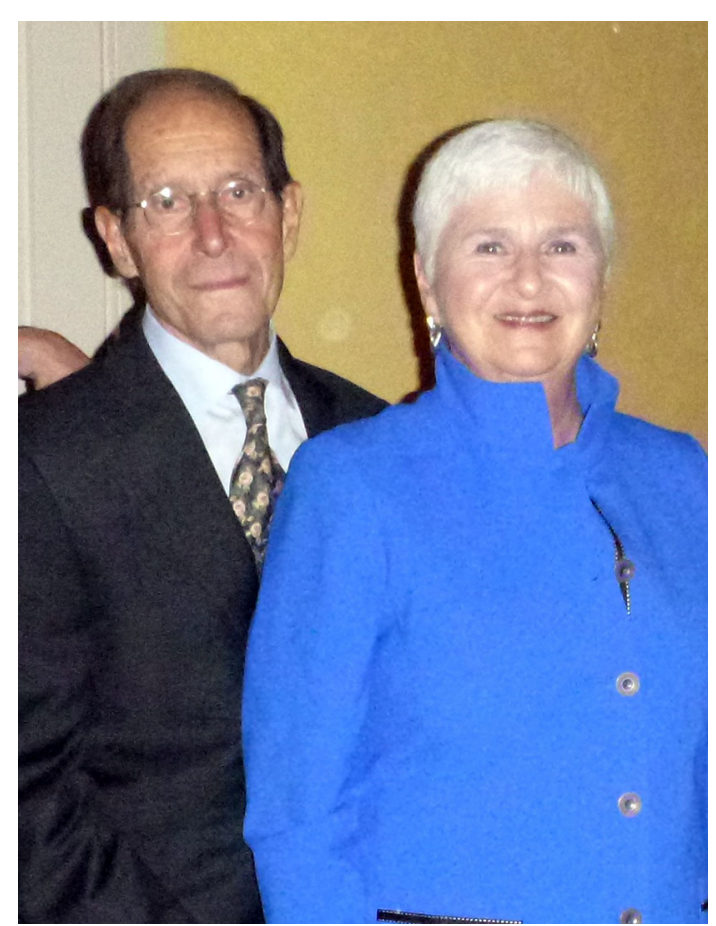

Fig. 2 Randall Marcus MD described his colleague and friend as a dedicated surgeon and scientist who truly cared about his family and orthopaedic surgery. Dr. Goldberg (L) is pictured with his wife, Harriet (R). Published with permission from Randall Marcus MD. 
were well aware of his accomplishments, and also of his intensity. He demanded a great deal from his residents, but he also showed them how to practice medicine in a scholarly way, according to Dr. Marcus.

"He pushed you to read, to constantly discover, and to always adapt," Dr. Marcus said. "Yes, he was intimidating, but in a good way. You wanted to be better for him."

A short time before his death, Victor learned that his family, friends, patients, residents, and colleagues donated the necessary funds to name a newly established chair-the Victor M. Goldberg Master Clinician's Chair in Orthopaedic Surgery-in his honor at University Hospitals Case Medical Center.

"He really was a visionary," Dr. Galante said. "His overall approach to his work is second to none. We talked about his intensity, and yes, he was an intense person. But he also had an intense love for his family and friends. He was also compassionate and understanding. $\mathrm{He}$ would not go more than 10 days without calling me to check in. He would ask about my health. Just to make sure I was doing okay. That was the type of person he was."

Dr. Goldberg's "relentless pursuit of excellence" reached far beyond his professional career.

"The first time I saw Victor must have been in the late 1960s or early 1970s," Dr. Galante said. "He was running in the street and his intensity was certainly coming through. That vision of him running still sticks in my mind."

An avid runner with a wiry 160pound frame, Dr. Goldberg would routinely outpace his friends when out on runs together. Perhaps Dr. Goldberg's boundless energy had something to do with his diet.

"He was a barrel of energy," Dr. Marcus said. "This high-strung guy who just had a real presence. He was so thin. He would be the worst person to go to lunch with. You would have a burger and there he is with his lettuce and carrots."

He played tennis and squash, but Dr. Goldberg truly loved to ski. His children always found it funny how the Brooklyn-born Dr. Goldberg fell in love with skiing considering his urban roots.

Dr. Goldberg is survived by his wife, Harriet (nee Mulfeld; Fig. 2), daughters, Rebecca L. (Dr. Lukas Richard Kolm) Goldberg, Eden L. (Jonathan N. Massey) Goldberg, his son Dr. Jonathan L. (Dr. Laura Dunn) Goldberg, and his grandchildren, Lily Samara Kolm, Sophia Rhea Goldberg, Hannah Elise Goldberg, Finley Samuel Massey, and Ayla Rose Massey.

\section{References}

1. Goldberg VM. Stem cells in osteoarthritis. HSS J. 2012;8:59-61.

2. Klein L, Heiple KG, Torzilli PA, Goldberg VM, Burstein AH. Prevention of ligament and meniscus atrophy by active joint motion in a nonweight-bearing model. J Orthop Res. 1989;7:80-85.

3. Kraay MJ, Darr OJ, Salata MJ, Goldberg VM. Outcome of metal-backed cementless patellar components: The effect of implant design. Clin Orthop Relat Res. 2001;392:239-244. 